\title{
Effect of texturized soy protein on quality characteristics of beef samosas
}

\author{
Omwamba, Mary ${ }^{a^{*}}$, Mahungu, Symon M. ${ }^{\mathrm{a}}$, and Faraj, Abdul K. ${ }^{\mathrm{a}}$ \\ ${ }^{a}$ Department of Dairy and Food Science \& Technology Egerton University, P.O Box 536-20115, Egerton, Kenya \\ ${ }^{*}$ Corresponding author \\ marynyambeki@yahoo.com \\ TEL/FAX: + $254(0) 711633247$
}

Received: 17 September 2013; Published online: 18 April 2014

\begin{abstract}
Texturized soy protein (TSP) granules obtained from defatted soy flour were used to replace beef at 25, 50, 75 and $100 \%$ levels in samosa stuffing. The moisture, protein and ash content of the stuffing increased with an increase in the amount of texturized soy protein while the fat content decreased significantly $(\mathrm{p}<0.05)$ with an increase in the amount of texturized soy protein. Sensory evaluation of baked samosas showed no significant $(\mathrm{p}>0.05)$ difference in appearance, taste and overall acceptability with inclusion of texturized soy protein. However there were significant $(\mathrm{p}<0.05)$ differences in flavour, texture and willingness to purchase between 100\% beef (control) and 100\% TSP samosas. There was a reduction in the moisture content while the protein, fat, ash and carbohydrate content increased in baked as compared to raw samples, both in the control and TSP50 samosas. The caloric value of the baked samosas was $24.07 \%$ lower in texturized soy protein added samples compared to $100 \%$ beef samples. Lipid oxidation increased with storage time from 0.25 to $0.68 \mathrm{mg}$ malonaldehyde $/ \mathrm{kg}$ in the control and from 0.21 to $0.39 \mathrm{mg}$ malonaldehyde $/ \mathrm{kg}$ in TSP50 samosas. The oxidation in the control was significantly $(\mathrm{p}<0.05)$ higher than in TSP50. The results suggest that texturized soy protein granules can be use with up to $50 \%$ addition in samosa products without significant differences in sensory attributes.
\end{abstract}

Keywords: Texturized soy protein; Samosa; Sensory properties; Lipid oxidation

\section{Introduction}

Functional meat products are generally produced by reformulating meat through incorporation of health promoting ingredients (FernandezGines, Fernandez-Lopez, Sayas-Barbera, \& Perez-Alvarez, 2005). One of the most widely used vegetable proteins in the meat industry is soy protein. This is due to its various technological benefits in influencing the functional characteristics of meat products. It is used extensively in meat products as a binder for improving yields, as a gelling agent to enhance emulsion stability and as a meat replacement to re- duce costs (Rentfrow, Brewer, Weingartner, \& Mckeith, 2004). Minced meat is used for the preparation of products such as patties, meatballs, burgers, kebabs and samosas etc. The minced meat is mixed with spices and condiment, shaped and then cooked by either frying or baking. Beef samosa is a deep fat fried or baked product prepared in a tetrahedral casing made of refined wheat flour which is then filled with a mixture of minced beef, spices and condiments. It is commonly eaten as a snack in many parts of the world.

High meat prices have prompted the food industry to produce non-meat proteins such as 
texturized soy protein (TSP) which is widely used in meat products as an extender to provide an economical high quality protein source. TSP refers to defatted soy flours or concentrates that are mechanically processed by extruders to obtain meat-like chewy textures when hydrated and cooked (Singh, Kumar, Sabapathy, \& Bawa, 2008). TSP absorbs at least 3 times its weight in water when cooked for at least $15 \mathrm{~min}$ in boiling water (Riaz, Yada, et al., 2004). It is regarded as a healthy choice because it is cholesterol-free, and low in fat and calories (Asgar, Fazilah, Huda, Bhat, \& Karim, 2010). Incorporation of up to $20 \%$ TSP in ground beef has been reported to decrease cooking and evaporative loss although sensory characteristics are affected (Kilic, Kankaya, Ekici, \& Orhan, 2010). Replacement of 15 or $30 \%$ meat in a ground beef mixture with hydrated TSP produced patties that were more tender than the controls although they had less beefy flavour which contributed to lower overall flavour quality (Deliza, Saldivar, Germani, Benassi, \& Cabral, 2002). Patties containing $30 \%$ soy protein shrunk less than controls or those containing $15 \%$ soy. Rentfrow et al., 2004 noted that more than $30 \%$ replacement of ground beef with non-solvent extracted TSP increased off flavour. However, Liu, Huffman, Egbert, Mccaskey, and Liu, 1991 found that patties containing textured isolated soy protein $(25 \%)$ to lean beef ( $10 \%$ fat) did not differ in beef flavour from controls. Angor and Al-Abdullah, 2010 found that textured soy alone increased moisture binding and protein level, while it lowered the flavour score of low fat $(14 \%)$ beef burgers compared to controls, but a combination of carrageenan $(0.5 \%)$, texturized soy $(1.5 \%)$ and trisodium phosphate $(0.5 \%)$ improved all sensory attributes.

Soy-based meat products like burgers, patties, meatballs and other forms of meat analogs are successful because of their healthy image, good taste and low cost. Acceptable texture and flavour often prove to be the biggest development challenges. It is up to the food scientist and the food industry in general to advance this technology even further towards improved taste and texture. The objective of this study was therefore to investigate the effect of TSP addition to beef samosa stuffing on chemical composition, sensory evaluation and lipid oxidation of samosas.

\section{Materials and Methods}

\subsection{Raw material}

Ground beef (approximately 19\% fat) was obtained from Gillanis butchery Nakuru, and textured soy protein (TSP) granules from Archer Daniels Midland (ADM) Company through Chemicals \& Solvents E.A. LTD. Four treatments of samosas were prepared, namely control, TSP25, TSP50, TSP75 and TSP100 using hydrated TSP granules at levels of $0 \%, 25 \%, 50 \%$, $75 \%$ and $100 \%(\mathrm{w} / \mathrm{w})$, respectively, in the formulation. TSP was hydrated using hot water $\left(80^{\circ} \mathrm{C}\right)$ in a ratio of TSP: water 1:2.75 $(\mathrm{w} / \mathrm{w})$ for 20 minutes. The hydration water contained $1 \%$ beef flavour as determined in preliminary investigation to estimate the amount of flavour to be used. The hydrated and squeezed TSP granules were then used in the formulation. All the other chemicals used were of analytical grade.

\subsection{Samosa preparation}

The ingredients used in the formulation of samosa stuffing for each treatment are shown in Table 2.2. Ingredients are expressed as a percentage of the total amount of hydrated TSP and minced beef combination. The onions were sautéed in a little oil until golden brown. The rest of the ingredients were added and the mixture cooked for 20 minutes. It was left to cool to room temperature before use as samosa stuffing. The dough for the samosa casing was prepared by mixing wheat flour, water and vegetable oil (in the ratio of 10:4:1) and kneading to a uniform mixture. The dough was divided into balls weighing $20 \mathrm{~g}$ each and rolled out in thin sheets of $3 \mathrm{~mm}$ thickness. The sheets were allowed to rest for $3 \mathrm{~min}$ at room temperature for the wet surface to dry before folding into triangular shapes. Twenty grams of samosa stuffing was filled in to the formed sheet and the ends sealed manually to give a triangular shape. 
76 Omwamba et al.

Table 1: Ingredients used in samosa formulation (\%)

\begin{tabular}{lrrrrr}
\hline \multirow{2}{*}{ Ingredients } & \multicolumn{5}{c}{ Formulation (\%) } \\
\cline { 2 - 6 } & Control & TSP25 & TSP50 & TSP75 & TSP100 \\
\hline Ground beef & 100.0 & 75.0 & 50.0 & 25.0 & 0.0 \\
Hydrated TSP & 0.0 & 25.0 & 50.0 & 75.0 & 100.0 \\
Coriander powder $*$ & 0.9 & 0.9 & 0.9 & 0.9 & 0.9 \\
Garlic powder* & 2.0 & 2.0 & 2.0 & 2.0 & 2.0 \\
Ginger powder* & 2.0 & 2.0 & 2.0 & 2.0 & 2.0 \\
Black pepper* & 1.8 & 1.8 & 1.8 & 1.8 & 1.8 \\
Salt* & 2.0 & 2.0 & 2.0 & 2.0 & 2.0 \\
Chopped onions* & 5.0 & 5.0 & 5.0 & 5.0 & 5.0 \\
\hline
\end{tabular}

* Ingredients for each treatment group are expressed as a percentage of the amount of minced beef and hydrated TSP combined.

\subsection{Proximate composition}

Moisture, protein (conversion factor of 6.25 from total nitrogen to total protein), fat and ash contents were determined by standard procedures of Association of Official Analytical Chemists (AOAC International, 1995). Moisture content was determined by using the air oven drying method. The protein content was analyzed by the Kjeldahl method, while the fat content was determined by the Soxhlet method. The ash content was determined by use of a muffle furnace. Carbohydrates content was calculated by subtracting the total of other components (\% moisture, $\%$ protein, $\%$ fat, and $\%$ ash) from $100 \%$. The total caloric value (kcal) was calculated from the results of proximate analysis on the basis of $100 \mathrm{~g}$ sample as reported by Mansour and Khalil, 1997 using Atwater values for fat (9.00 $\mathrm{kcal} / \mathrm{g})$, protein $(4.02 \mathrm{kcal} / \mathrm{g}$ ) and carbohydrates $(3.87 \mathrm{kcal} / \mathrm{g})$. All experiments were performed in triplicate and expressed per $100 \mathrm{~g}$ of sample on wet basis.

\subsection{Sensory evaluation}

Fifty trained panelists aged between 20 and 25 years participated in the sensory evaluation which was carried out at the sensory laboratory of the Department of Food Science and Technology, Egerton University. The procedures described in the IFT Guideline, 1981 for sensory evaluation were followed. Samples were coded with three-digit random letters and the order of presentation randomized to avoid bias. A 5-point Hedonic scale was used to evaluate the attributes of taste, flavour, appearance, texture, overall acceptability and willingness to purchase. Samosas were baked at a temperature of $180^{\circ} \mathrm{C}$ for $20 \mathrm{~min}$ (the crust appeared golden-brown) and randomly served to the panelists. Water was provided to rinse the mouth between sample tasting. Selection of panelists was based on age, willingness to participate and allergies to soy bean or any of the ingredients used. Panelists signed a consent form informing them of the nature of the samosa samples they would evaluate before engaging in the sensory exercise. The evaluation was replicated 3 times and a total of 150 observations were made for each treatment.

\subsection{Statistical analysis}

A one-factor Completely Randomized Design (CRD), involving five different levels of hydrated TSP granule in the samosas was used. The five experimental units comprised of control, TSP25, TSP50, TSP75 and TSP100. Data were subjected to Analysis of Variance (ANOVA) using SPSS Inc., 2006 version 15.0.1 for Windows. Significant differences between means $(\mathrm{p}<0.05)$ were determined using Duncan Multiple Range Test (DMRT). 


\section{Results and Discussion}

\subsection{Proximate composition}

Table 3.1 shows the proximate composition results of samosa stuffing. The protein and ash content increased in all the treatments with an increase in the amount of TSP added although there was no significant difference $(\mathrm{p}<0.05)$ between the control (without TSP) and the treatment with $25 \%$ TSP substitution. The moisture content increased with added TSP but the increase was not significant $(\mathrm{p}>0.05)$. The control treatment had $60.25 \%$ moisture which was lower than the treatments with TSP. This clearly shows that addition of TSP increased moisture content due to the high water content in the TSP. The fat content was significantly $(\mathrm{p}<0.05)$ reduced with increase in the amount of TSP added. The fat content in control stuffing was $20.01 \%$ while that for $100 \%$ TSP was $1.02 \%$ representing approximately $95 \%$ reduction in fat. This reduction was due to the low fat content of rehydrated TSP used to replace minced beef. Rhee and Smith, 1983 reported a decrease in fat content in raw ground beef patties with addition of up to $30 \%$ rehydrated TSP. Similar trends were reported by Qammar, Mohy-ud-Din, Huma, Sameen, and Khan, 2010 and Kassem, Emara, et al., 2010 when TSP was used in pizza toppings and to substitute beef in beef burgers, respectively.

\subsection{Sensory evaluation}

The sensory attributes of samosas with beef and added rehydrated TSP granules were assessed and the results are shown in Table 3. Up to $20 \%$ TSP can be incorporated into ground beef to decrease cooking loss and decrease evaporative loss although it affects sensory characteristics (Kilic et al., 2010). In this study appearance, taste and overall acceptability of samosas were not significantly $(\mathrm{p}>0.05)$ affected by the addition of hydrated TSP granules in the formulation. There was a significant $(\mathrm{p}<0.05)$ difference between the flavour, texture and willingness to purchase of the control and 100\% TSP samosas. Generally there was a reducing trend in all the attributes with an increase in the amount of TSP used ex- cept for texture. Hydrated TSP (15 or 30\%) used to replace meat in a ground beef mixture can produce patties that are more tender than controls, however they have less beefy flavour and the overall flavour quality is lower (Deliza et al., 2002). In this study, addition of TSP to $50 \%$ level was not significantly different in flavour and texture while the taste and overall acceptability of the control and $100 \%$ TSP were not significantly different. The beef flavour that was added during TSP hydration may have contributed to this. When hydrated, TSP provides a meat-like texture that contributes to mouth feel (Singh et al., 2008). The texture of the samosas was assessed based on juiciness. When up to $50 \%$ TSP was added the samosas were significantly $(\mathrm{p}<0.05)$ rated higher than the control. The increase in the score for texture in terms of juiciness with increase in the amount of TSP in the samosas can be attributed to the soy proteins which are capable of providing functional properties to a formulation such as yield, gelling/textural capabilities, fat emulsification and water binding (Pietrasik, Jarmoluk, \& Shand, 2007). Non-meat protein sources such as egg, whey protein and TSP are able to improve the flavour and texture of burgers by increasing the fat and moisture binding ability (Gujral, Kaur, Singh, \& Sodhi, 2002; Rentfrow et al., 2004; Kassem, Emara, et al., 2010).

\subsection{Proximate chemical composition and caloric value of control and TSP50 baked samosas}

Baking of the samples resulted in a $6.6 \%$ and $2.4 \%$ decrease in the moisture content of the control and the TSP50 samples, respectively (Table 4). This higher loss of moisture from the control could be the reason for the low texture score of the samosas during sensory evaluation. The protein, fat and ash content increased in the baked samples compared to the raw samples (Table 4). This can be attributed to the change in concentration due to water evaporation and fat loss. In both products, reduction in moisture content led to an increase in other chemical components. Kassem, Emara, et al., 2010 reported an increase in fat, protein and ash in deep fat fried soy and 
78 Omwamba et al.

Table 2: Proximate chemical composition of samosa stuffing with different amounts of TSP

\begin{tabular}{lcccc}
\hline \multirow{2}{*}{ Samples } & \multicolumn{4}{c}{ Parameters (\%) } \\
\cline { 2 - 5 } & Moisture & Protein & Fat & Ash \\
\hline Control & $60.52 \pm 0.37^{a}$ & $18.26 \pm 0.28^{a}$ & $20.01 \pm 0.18^{e}$ & $0.89 \pm 0.14^{a}$ \\
TSP25 & $60.77 \pm 0.25^{a}$ & $18.54 \pm 0.19^{a b}$ & $16.08 \pm 0.19^{d}$ & $1.02 \pm 0.13^{a}$ \\
TSP50 & $60.95 \pm 0.20^{a}$ & $18.82 \pm 0.20^{b}$ & $10.76 \pm 0.13^{c}$ & $1.99 \pm 0.22^{b}$ \\
TSP75 & $61.01 \pm 0.31^{a}$ & $19.10 \pm 0.24^{b c}$ & $5.69 \pm 0.17^{b}$ & $2.42 \pm 0.14^{c}$ \\
TSP100 & $61.32 \pm 0.22^{a}$ & $19.37 \pm 0.23^{c}$ & $1.02 \pm 0.18^{a}$ & $3.63 \pm 0.19^{d}$ \\
\hline
\end{tabular}

Means in the same column followed by the same letter are not significantly different at $\mathrm{p}<0.05$

Table 3: Sensory evaluation of baked samosas with different amounts of TSP

\begin{tabular}{|c|c|c|c|c|c|c|}
\hline \multirow[b]{2}{*}{ Sample } & \multicolumn{6}{|c|}{ SENSORY ATTRIBUTES $^{1}$} \\
\hline & Appearance $^{2}$ & Flavour $^{2}$ & Texture $^{3}$ & Taste $^{2}$ & $\begin{array}{c}\text { Overall } \\
\text { Acceptance }^{4}\end{array}$ & Purchase $^{5}$ \\
\hline Control & $4.3 \pm 1.8^{a}$ & $4.5 \pm 1.6^{a}$ & $3.7 \pm 1.8^{b}$ & $4.3 \pm 2.1^{a}$ & $4.4 \pm 2.3^{a}$ & $4.4 \pm 1.9^{a}$ \\
\hline TSP25 & $4.4 \pm 2.1^{a}$ & $4.3 \pm 1.7^{a b}$ & $4.1 \pm 1.9^{a b}$ & $4.2 \pm 2.0^{a}$ & $4.2 \pm 2.1^{a}$ & $4.3 \pm 2.2^{a b}$ \\
\hline TSP50 & $4.3 \pm 2.3^{a}$ & $4.0 \pm 2.0^{a b}$ & $4.2 \pm 1.8^{a b}$ & $3.9 \pm 2.1^{a}$ & $4.0 \pm 1.9^{a}$ & $3.9 \pm 2.1^{a b}$ \\
\hline TSP75 & $4.1 \pm 2.1^{a}$ & $3.8 \pm 1.8^{b}$ & $4.3 \pm 1.7^{a}$ & $3.8 \pm 1.9^{a}$ & $3.9 \pm 1.8^{a}$ & $4.0 \pm 2.0^{a b}$ \\
\hline TSP100 & $4.1 \pm 1.9^{a}$ & $3.8 \pm 2.1^{b}$ & $4.5 \pm 2.2^{a}$ & $3.7 \pm 2.1^{a}$ & $3.8 \pm 2.3^{a}$ & $3.8 \pm 1.8^{b}$ \\
\hline
\end{tabular}

1 - Means in the same column followed by the same letter are not significantly different at $\mathrm{p}<0.05$.

2 - 5 Point hedonic scale: $5=$ very desirable, $4=$ desirable, $3=$ neither desirable nor undesirable, $2=$ undesirable, $1=$ very undesirable

3 - 5 Point hedonic scale: $5=$ juicy, $4=$ slightly juicy, $3=$ neither juicy nor dry, $2=$ slightly dry, $1=$ dry

4 - 5 Point hedonic scale: $5=$ like extremely, $4=$ like, $3=$ neither like nor dislike, $2=$ dislike, $1=$ dislike extremely

5 - 5 Point hedonic scale: $5=$ definitely will buy, $4=$ will buy, $3=$ will neither buy nor not buy, $2=$ will not buy, $1=$ definitely will not buy

Table 4: Proximate chemical composition and total energy of control (100\% beef) and $50 \%$ TSP raw and baked samosas

\begin{tabular}{lcccc}
\hline & \multicolumn{2}{c}{ Control } & \multicolumn{2}{c}{ TSP50 } \\
& Raw & Baked & Raw & Baked \\
\hline Moisture (\%) & $61.47 \pm 0.20$ & $57.40 \pm 0.16$ & $61.98 \pm 0.42$ & $60.48 \pm 0.11$ \\
Protein (\%) & $17.35 \pm 0.21$ & $20.48 \pm 0.23$ & $18.01 \pm 0.15$ & $19.01 \pm 0.19$ \\
Fat (\%) & $19.18 \pm 0.19$ & $19.78 \pm 0.22$ & $10.21 \pm 0.17$ & $10.41 \pm 0.18$ \\
Ash (\%) & $1.03 \pm 0.31$ & $1.23 \pm 0.27$ & $2.03 \pm 0.37$ & $2.13 \pm 0.25$ \\
Carbohydrates (\%) & $0.97 \pm 0.32$ & $1.11 \pm 0.19$ & $7.77 \pm 0.25$ & $7.97 \pm 0.31$ \\
Caloric Value (kcal/100g) & $246.17 \pm 0.13$ & $264.65 \pm 0.15$ & $194.36 \pm 0.20$ & $200.95 \pm 0.11$ \\
\hline
\end{tabular}




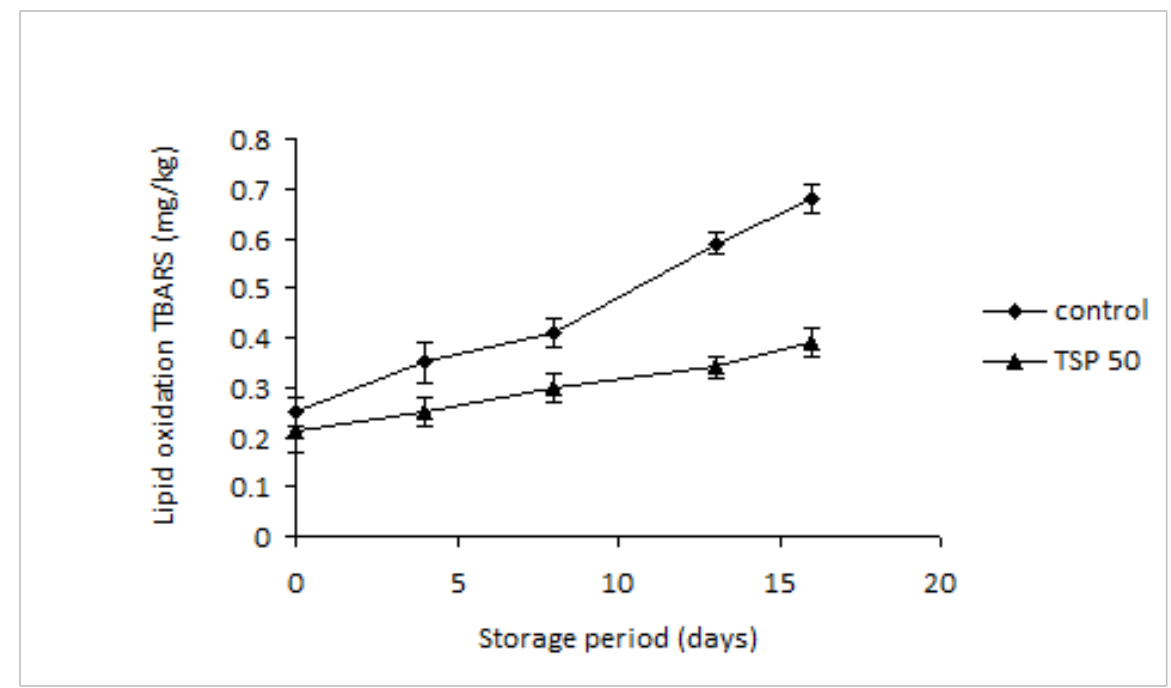

Figure 1: Effect of refrigerated storage $\left(0 \pm 1{ }^{\circ} \mathrm{C}\right)$ on lipid oxidation in baked samosas

vegetable-extended beef burgers. The carbohydrate content in TSP50 samples was higher compared to the control in both raw and baked samples probably due to the high carbohydrate content of TSP.

The higher energy values (kcal/100 g) of the control compared to the TSP50 samosas (Table 4) could be due to the high fat content in the minced beef compared to TSP which was made from defatted soy. When part of the minced beef was replaced with hydrated TSP, the fat and therefore the energy content declined. The use of $50 \%$ TSP led to a $21.05 \%$ and $24.07 \%$ reduction in total caloric value in raw and baked samosas, respectively.

\subsection{Lipid oxidation}

When meat and meat products are stored under frozen conditions, microbial spoilage may be delayed but fat deterioration occurs and the meat constituents may be oxidized. A general trend of increase in Thiobarbituric Acid Reactive Substances (TBARS) during refrigerated and frozen storage of meat and meat products has been reported by many workers (Devatkal, Mendiratta, \& Kondaiah, 2004; Rajkumar, Agnihotri, \& Sharma, 2004). Figure 1 shows the trend in TBARS values of control and TSP50 baked samosas which is indicative of lipid oxidation. Lipid oxidation gradually increased in all samples with an increase in storage period (0-16 days) although higher values were found in the control compared to TSP50. The TBARS of baked samosa ranged from 0.25 to 0.68 and 0.21 to 0.39 $\mathrm{mg} / \mathrm{kg}$ in the control and TSP50, respectively, during the 16 days of storage at $0 \pm 1{ }^{\circ} \mathrm{C}$. These values are lower than the threshold TBARS value of $2.0 \mathrm{mg}$ maloaldehyde $/ \mathrm{kg}$ (Witte, Krause, \& Bailey, 1970). (Tarladgis, Watts, \& Younathan, 1960) reported that the minimum threshold value or acceptable TBARS limit of cooked meat products during storage was $0.50-1.0 \mathrm{mg}$ as detected by a trained panel. The results in this study indicate that addition of TSP has the ability to slow lipid oxidation. This could be due to lower fat content in the product and an antioxidant effect of components of soy granules. Angor and AlAbdullah, 2010 reported lower TBARS values in beef burgers with addition of texturized soy and trisodium phosphate. The use of soy protein has been shown to suppress lipid oxidation in cooked pork patties and meatballs during storage (PenaRamos \& Xiong, 2003; Ulu, 2004). 


\section{Conclusions}

A level of up to $50 \%$ TSP can be used in beef samosa production to obtain acceptable products that have better textural properties in which the flavour and taste are not significantly different from $100 \%$ beef samosas. Using these and other soy foods to replace foods high in animal protein that contain saturated fat and cholesterol may confer benefits to cardiovascular health. There are ongoing studies on microbial quality of the raw and baked samosas to determine shelf life and sensory changes. There is need to develop healthier meat products, containing lower fat and incorporating health enhancing ingredients. Soy products are known for their beneficial effect in reducing cardiovascular diseases and overall health. Reducing the fat content of beef samosas can make a significant contribution to human health and promote the consumption of these types of foods.

\section{Acknowledgements}

The authors are grateful to the National Soybean Research Laboratory (NSRL), University of Illinois for the research funds and the caterers at Egerton University cafeteria for preparing the samosas.

\section{References}

Angor, M. M. \& Al-Abdullah, B. M. (2010). Attributes of low-fat beef burgers made from formulations aimed at enhancing product quality. Journal of Muscle Foods, 21(2), 317-326.

AOAC International. (1995). Official methods of analysis of AOAC International. Vol. 2, 16th edition. Arlington, VA, USA, Association of Analytical Communities.

Asgar, M. A., Fazilah, A., Huda, N., Bhat, R., \& Karim, A. A. (2010). Nonmeat protein alternatives as meat extenders and meat analogs. Comprehensive Reviews in Food Science and Food Safety, 9(5), 513-529.
Deliza, R., Saldivar, S. O. S., Germani, R., Benassi, V. T., \& Cabral, L. C. (2002). The effects of colored textured soybean protein (tsp) on sensory and physical attributes of ground beef patties. Journal of Sensory Studies, 17(2), 121-132. doi:10.1111/ j . 1745-459X.2002.tb00337.x

Devatkal, S., Mendiratta, S. K., \& Kondaiah, N. (2004). Quality characteristics of loaves from buffalo meat, liver and vegetables. Meat Science, 67(3), 377-383. doi:10.1016/ j.meatsci.2003.11.006

Fernandez-Gines, J. M., Fernandez-Lopez, J., Sayas-Barbera, E., \& Perez-Alvarez, J. A. (2005). Meat products as functional foods: a review. Journal of Food Science, 70(2), R37-R43.

Gujral, H. S., Kaur, A., Singh, N., \& Sodhi, N. S. (2002). Effect of liquid whole egg, fat and textured soy protein on the textural and cooking properties of raw and baked patties from goat meat. Journal of Food Engineering, 53(4), 377-385. doi:10.1016 / S02608774(01)00180-7

IFT Guideline. (1981). Sensory evaluation guide for testing food and beverage products. Food technology, 35(11), 50-59. Dethmers, A. E. and Civille, G. V. and Eggert, J. M. and Erhardt, J. P. and Hootman, R. C. and Jehle, K. and Kluter, R. A. and Low, P. and Moskowitz, H. R. and Pangborn, R. M. and Others.

Kassem, M. A. G., Emara, M. M. T. et al. (2010). Quality and acceptability of value-added beef burger. World Journal of Dairy and Food Sciences, 5(1), 14-20.

Kilic, B., Kankaya, T., Ekici, Y. K., \& Orhan, H. (2010). Effect of textured soy protein on quality characteristics of low fat cooked kofte (turkish meatball). Journal of Animal and Veterinary Advances, 9(24), 30483054.

Liu, M. N., Huffman, D. I., Egbert, W. R., Mccaskey, T. A., \& Liu, C. W. (1991). Soy protein and oil effects on chemical, physical and microbial stability of lean ground-beef patties. Journal of Food Science, 56(4), 906-912. doi:10.1111/j.1365-2621.1991. tb14603.x 
Mansour, E. H. \& Khalil, A. H. (1997). Characteristics of low-fat beefburger as influenced by various types of wheat fibers. Food Research International, 30(3), 199-205.

Pena-Ramos, E. A. \& Xiong, Y. L. L. (2003). Whey and soy protein, hydrolysates inhibit lipid oxidation in, cooked pork patties. Meat Science, 64(3), 259-263. doi:10. 1016/S0309-1740(02)00187-0

Pietrasik, Z., Jarmoluk, A., \& Shand, P. J. (2007). Effect of non-meat proteins on hydration and textural properties of pork meat gels enhanced with microbial transglutaminase. LWT-Food Science and Technology, 40(5), 915-920. doi:10.1016/j.lwt. 2006.03 .003

Qammar, G., Mohy-ud-Din, G., Huma, N., Sameen, A., \& Khan, M. I. (2010). Textured soy protein (tsp) as pizza topping. Nutrition \& Food Science, 40(6), 551-556. doi:10.1108/00346651011090356

Rajkumar, V., Agnihotri, M. K., \& Sharma, N. (2004). Quality and shelf-life of vacuum and aerobic packed chevon patties under refrigeration. Asian Australasian Journal of Animal Sciences, 17(4), 548-553.

Rentfrow, G., Brewer, M. S., Weingartner, K. E., \& Mckeith, F. K. (2004). Sensory characteristics of beef and pork processed meats containing nonsolvent extracted texturized soy protein. Journal of Muscle Foods, 15(4), 225-234.

Rhee, K. S. \& Smith, G. C. (1983). Effect of cooking on cholesterol content of patties containing different amounts of beef, textured soy protein and fat. Journal of Food Science, 48(1), 268-269.

Riaz, M. N., Yada, R. Y. et al. (2004). Texturized soy protein as an ingredient. Proteins in food processing, 517-558.

Singh, P., Kumar, R., Sabapathy, S. N., \& Bawa, A. S. (2008). Functional and edible uses of soy protein products. Comprehensive Reviews in Food Science and Food Safety, 7(1), 14-28. 12 World Congress of Food Science and Technology, Chicago, IL, JUL 16-20, 2003. doi:10.1111/j.1541-4337.2007. 00025. $\mathrm{x}$

SPSS Inc. (2006). SPSS Version 15.0. Chicago, IL: SPSS.
Tarladgis, B. G., Watts, B. M., \& Younathan, L., M. T .And Dugan. (1960). A distillation method for the quantitative determination of malonaldehyde in rancid foods. Journal of the Acoustical Society of Americahe American Oil Chemists Society, 37(1), 4448. doi:10.1007/BF02630824

Ulu, H. (2004). Effect of wheat flour, whey protein concentrate and soya protein isolate on oxidative processes and textural properties of cooked meatballs. Food Chemistry, 87(4), 523-529. doi:10.1016/j.foodchem. 2004.01.002

Witte, V. C., Krause, G. F., \& Bailey, M. E. (1970). A new extraction method for determining 2-thiobarbituric acid values of pork and beef during storage. Journal of Food Science, 35(5), 582-585. doi:10.1111/j . 1365-2621.1970.tb04815.x 